Applied Remote Sensing

\title{
Approach to developing numeric water quality criteria for coastal waters: transition from SeaWiFS to MODIS and MERIS satellites
}

Blake A. Schaeffer

James D. Hagy

Richard P. Stumpf 


\title{
Approach to developing numeric water quality criteria for coastal waters: transition from SeaWiFS to MODIS and MERIS satellites
}

\author{
Blake A. Schaeffer, ${ }^{a}$ James D. Hagy, ${ }^{a}$ and Richard P. Stumpf ${ }^{b}$ \\ ${ }^{a}$ Gulf Ecology Division, US EPA National Health and Environmental Effects Research \\ Laboratory, 1 Sabine Island Drive, Gulf Breeze, Florida 32561 \\ schaeffer.blake@epa.gov \\ ${ }^{b}$ National Oceanic and Atmospheric Administration, National Ocean Service, Center for Coastal \\ Monitoring and Assessment, 1305 East-West Highway, n/SCI1, Silver Spring, Maryland 20910
}

\begin{abstract}
States can adopt numeric water quality criteria into their water quality standards to protect the designated uses of their coastal waters from eutrophication impacts. The first objective of this study was to provide an approach for developing numeric water quality criteria for coastal waters based on archived SeaWiFS ocean color satellite data. The second objective was to develop an approach for transferring water quality criteria assessments to newer ocean color satellites, such as MODIS and MERIS. Measures of SeaWiFS, MODIS, and MERIS chlorophyll- $a\left(\mathrm{Chl}_{\mathrm{RS}^{-}} a, \mathrm{mgm}^{-3}\right)$ were resolved across Florida's coastal waters between 1998 and 2009. Annual geometric means of SeaWiFS Chl $\mathrm{RS}^{-} a$ were evaluated to determine a quantitative reference baseline from the 90th percentile of the annual geometric means. A method for transferring to multiple ocean color sensors was implemented with SeaWiFS as the reference instrument. The $\mathrm{Chl}_{\mathrm{RS}^{-}}-a$ annual geometric means for each coastal segment from MODIS and MERIS were regressed against SeaWiFS to provide a similar response among all three satellites. Standardization factors for each coastal segment were calculated based on the differences between 90th percentile from SeaWiFS to MODIS and SeaWiFS to MERIS. This transfer approach was allowed for future assessments, typically with $<7 \%$ difference in the calculated criteria. (C) The Authors. Published by SPIE under a Creative Commons Attribution 3.0 Unported License. Distribution or reproduction of this work in whole or in part requires full attribution of the original publication, including its DOI. [DOI: 10.1117/1.JRS.7.073544]
\end{abstract}

Keywords: ocean color; satellite; remote sensing; nutrients; numeric criteria; chlorophyll- $a$.

Paper 13079 received Mar. 15, 2013; revised manuscript received May 7, 2013; accepted for publication May 13, 2013; published online Jun. 18, 2013.

\section{Introduction}

Extensive modification of landscapes associated with increased human population, land development, and agricultural activities contributes to increased delivery of nitrogen and phosphorus to the coastal waters. ${ }^{1}$ Ecological impacts associated with anthropogenic nutrient enrichment include increased phytoplankton production and biomass, harmful algal blooms, decreased water clarity, degradation of submerged aquatic vegetation habitats, and hypoxia. ${ }^{2-4}$ In the USA, the federal Clean Water Act (CWA) requires U.S. states to identify designated uses of their waters and when necessary to develop science-based water quality criteria to ensure protection of the designated uses. Numeric water quality criteria are concentrations or levels of a pollutant that, if achieved, provide an expectation that designated uses will be supported. The U.S. Environmental Protection Agency established a national strategy for development of numeric criteria identifying chlorophyll- $a$ as a nutrient-related response variable. ${ }^{5}$

Eutrophication assessment frameworks in Europe and the USA use a variety of approaches for assessing nutrient pollution impact and status in marine coastal waters. Such frameworks include the Oslo Paris (OSPAR) Commission Common Procedure, Water Framework Directive (WFD) of the European Union, Assessment of Estuarine Trophic Status (ASSETS) in the USA, Marine Strategy Framework Directive (MSFD) from the European Commission, French Research Institute for Exploration of the Sea (IFREMER) method, and Helsinki 
Commission (HELCOM) Eutrophication Assessment Tool (HEAT). One common element is that these assessment frameworks involve defining a baseline and then assessing current conditions to assign a level of eutrophication or overall ecological status to coastal waters. These frameworks collectively support the use of phytoplankton chlorophyll- $a$ as an indicator of the direct effects of nutrient pollution, and as an immediate biological response to excess nutrients. ${ }^{6,7}$ Chlorophyll- $a$ concentrations above the baseline are considered a symptom of water quality degradation associated with nutrient pollution. After the baseline is exceeded, the frameworks require specific management actions be taken to address nutrient pollution. The IFREMER method, OSPAR, ASSETS, and WFD all use the 90th percentile of a historical chlorophyll$a$ reference data set. ${ }^{6}$ The 90th percentile captures concentration variation over time and space and chlorophyll data are nonparametric, resulting in greater statistical confidence when criteria are exceeded. ${ }^{8}$

Schaeffer et al. ${ }^{9}$ previously evaluated a reference condition approach to numeric criteria development using satellite remote sensing to derive chlorophyll- $a\left(\mathrm{Chl}_{\mathrm{RS}}-a\right)$. A reference condition approach involves computing criteria based on water quality present in a water body that can be interpreted as supporting, or not impairing, designated uses (e.g., aquatic life uses).The reference condition could be based on data collected in the past when the water body was determined to be minimally impacted by nitrogen or phosphorus pollution. The Sea-viewing Wide Field-of-view Sensor (SeaWiFS) satellite was used to determine a quantitative reference baseline to protect coastal waters from eutrophication impacts. Cumulative distribution functions were calculated for $\mathrm{Chl}_{\mathrm{RS}^{-}} a$, and numeric criteria values were selected as the 90th percentile from trailing 3-year median and 75th percentile values within each coastal segment during the reference period. Statistical significance of criteria exceedance was evaluated using a binomial test. In this study, we evaluate a reference condition approach for numeric criteria development that uses the 90th percentile of annual geometric means between 1998 and 2009 from the SeaWiFS mission. In addition, we present an approach to enable transition of assessments from the SeaWiFS to the Moderate Resolution Imaging Spectroradiometer Aqua (MODIS) and the Medium Resolution Imaging Spectroradiometer (MERIS). We illustrate the approach using data for Florida coastal waters to 3 nautical miles (NM) from shore, excluding waters within semienclosed basins including estuaries.

Satellite remote sensing uses low Earth orbiting satellites to derive ocean color products on a global scale ${ }^{10}$ at frequent revisit intervals. Remote sensing has, most commonly, been used for open ocean applications. However, these satellites are also useful for applications in near-coastal waters. ${ }^{11,12}$ Interferences from colored dissolved organic matter (CDOM), turbidity, and bottom reflectance within near-coastal waters were previously reviewed and addressed in Schaeffer et al. ${ }^{9}$ Three sensors, SeaWiFS, MODIS, and MERIS, were used in this study to quantify an indicator of $\mathrm{Chl}_{\mathrm{RS}}-a$. SeaWiFS became operational in 1997 and concluded in 2010, whereas MODIS and MERIS became operational in 2002. Since the SeaWiFS satellite mission concluded in 2010, we illustrate an approach for transitioning to newer ocean color satellites, such as MODIS and MERIS for future assessments. At the time of writing, the European Space Agency also declared the end of the MERIS mission. Regardless, the approach remains applicable for future ocean color mission assessments using the new and anticipated sensors such as the Visible Infrared Imager Radiometer Suite (VIIRS) launched November 2011, the Ocean and Land Color Instrument (OLCI) on Sentinel-3 scheduled for launch in early 2014, and Pre-ACE, aerosols, clouds, and ecosystem (PACE) satellite scheduled for launch in 2018 or later. The analytical approach proposed in this study could be used in perpetuity to transfer assessments to new missions as they become available and older missions conclude.

Finally, acknowledging the potential for Karenia brevis blooms to increase coastal chlorophyll concentrations, we also discuss the possibility of including or excluding $K$. brevis blooms within the context of a reference condition approach to numeric water quality criteria development. $K$. brevis is a harmful algal bloom dinoflagellate that frequently occurs in the coastal waters of Florida and produces blooms that have significant implications for human health and aquatic life. ${ }^{13}$ While most blooms occur in Florida along the Gulf Coast, K. brevis can also impact Florida's Atlantic Coast (AC). This organism produces brevetoxins, a neurotoxin that can cause respiratory irritation $\left(>10^{3}\right.$ cells $\left.\mathrm{L}^{-1}\right)$ through aerosolization, neurotoxic shellfish poisoning through consumption of contaminated shellfish $\left(>5 \times 10^{3}\right.$ cells L $\left.^{-1}\right)$, 
and large fish kills ( $>1$ to $2.5 \times 10^{5}$ cells $\mathrm{L}^{-1}$ ). Mortality among shore birds and manatees has also been linked to $\mathrm{K}$. brevis blooms. ${ }^{14}$ Anthropogenic nutrients have been implicated in the maintenance phase of these blooms when advected to near-shore waters, but not in the initiation or development. ${ }^{15}$

\section{Methods}

\subsection{Delineation of Areas of Interest}

For the purposes of this study, Florida's coastal waters were first divided into three regions: the Florida Panhandle (FP), the West Florida Shelf (WFS), and the AC. The delineation into three regions was previously suggested by Tomlinson et al. ${ }^{16}$ and was based on CWA jurisdictional considerations of U.S. law. Coastal waters were further subdivided into 74 coastal segments based on the Florida Department of Environmental Protection's (FDEP) Water Body Identification System (WBIDs), which start at the land margin and extend seaward to 3 NM. Segment distance along the coast was typically between 6 and 14 NM depending on the state's contour at a particular location. Coastal WBIDs located near an estuary pass were typically centered at the pass. This study included 17 coastal segments in the FP between the Alabama border and St. Joseph Bay, 19 segments on the WFS from Anclote Bay to Rookery Bay, and 38 AC segments from Biscayne Bay to the Georgia border (Fig. 1). Areas within south Florida, including the Florida Keys, were omitted because significant bottom reflectance confounded derivation of $\mathrm{Chl}_{\mathrm{RS}^{-}} a$. The area between St. Joseph Bay and Anclote Bay was also omitted because coastal seagrass coverage ${ }^{17}$ and extremely high colored dissolved organic carbon exports from rivers ${ }^{18}$ were expected to confound derivation of $\mathrm{Chl}_{\mathrm{RS}^{-}} a$.

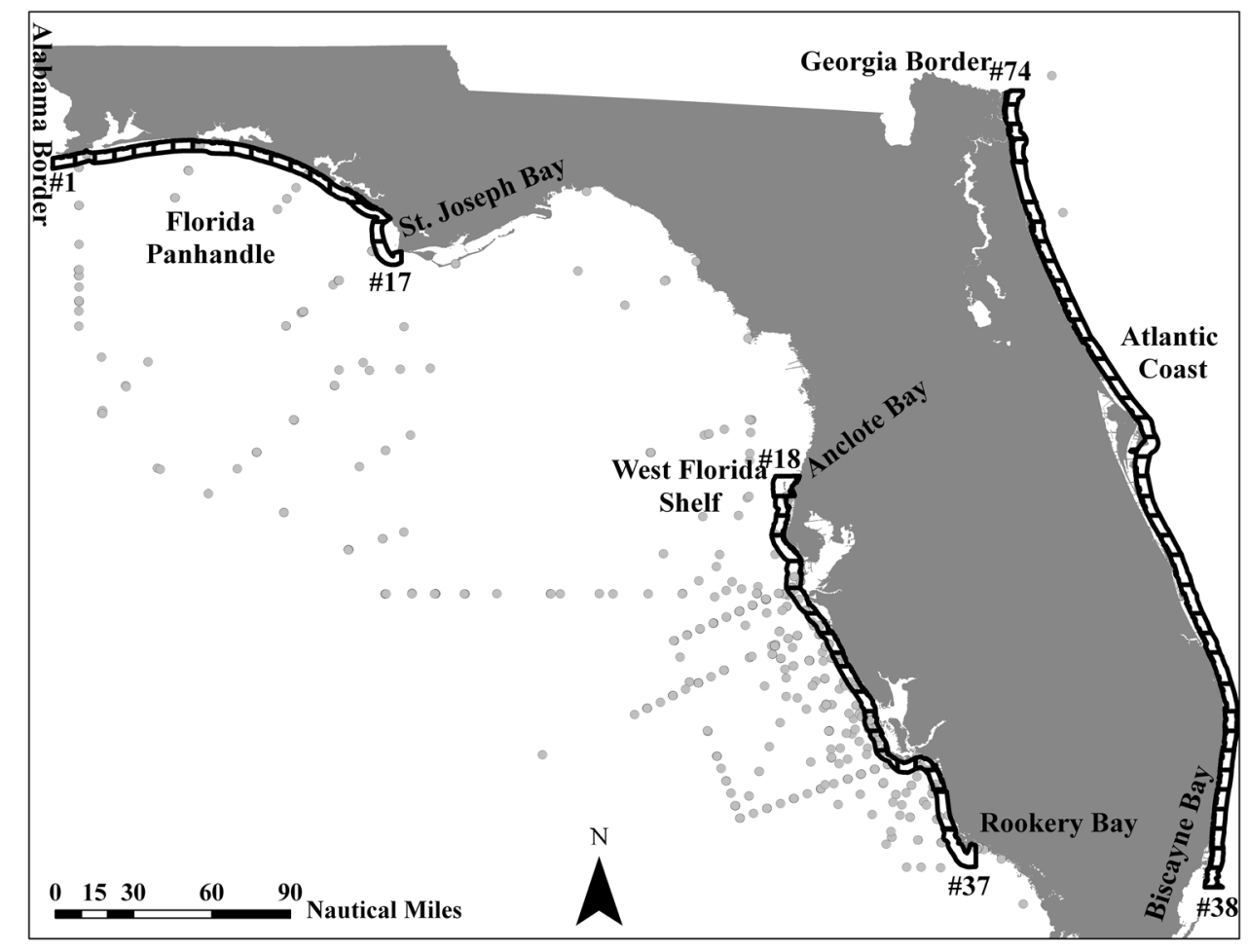

Fig. 1 Station data and coastal segments used in satellite remote sensing analysis of $\mathrm{Chl}_{\mathrm{RS}}-\mathrm{a}$. Coastal segments were delineations proposed in this approach to develop numeric chlorophyll criteria for the FP, WFS, and AC. Points indicate the station data used to compare Chl-a to satellite remote sensing observations of $\mathrm{Chl}_{\mathrm{RS}}-a$. Numbers are coastal segment numbers ranging from 1 to 74 . 
The seaward boundary of the WBID was extended to 4 NM so that the outer boundary of satellite data bins included in the analysis would be approximately $3 \mathrm{NM}$. If the boundary was set such that any pixel intersecting $3 \mathrm{NM}$ would be excluded, then the analysis would generally be limited to well inside $3 \mathrm{NM}$.

\subsection{Satellite Data}

Satellite ocean color data were obtained from the National Aeronautics and Space Administration's (NASA) Ocean Color Web ${ }^{19}$ and European Space Agency's MERIS Catalogue and Inventory (MERCI) website. SeaWiFS and MODIS provided daily images with pixels having a nominal 1.1 and $1.0 \mathrm{~km}$ spatial resolution at nadir, respectively. MERIS provided images every 2 to 3 days with nominal nadir resolution of $1.2 \mathrm{~km}$. SeaWiFS provided a historical time-series back to 1997, whereas MODIS and MERIS data collections began in 2002. SeaWiFS data (reprocessing R2009) spanned complete calendar years from 1998 to 2009. MODIS (reprocessing R2009.1) and MERIS (second reprocessing) data spanned complete calendar years from 2003 to 2009. Imagery covered the region between 23.0 to $31.0^{\circ} \mathrm{N}$ and 79.0 to $88.0^{\circ} \mathrm{W}$. The SeaWiFS Data Analysis System (SeaDAS) version 6.1 (Ref. 20) was used to process data from all three missions that met all standard quality control flags from level-1 to level-3 8-day composites. Atmospheric correction algorithms included the standard near-infrared correction for coastal waters. ${ }^{21-23}$

\subsection{Field Data}

Field data used for satellite validation were from the Northeastern Gulf of Mexico project (NEGOM), obtained from the NOAA National Oceanographic Data Center (NODC); the Ecology and Oceanography of Harmful Algal Blooms project (ECOHAB); the Fish and Wildlife Research Institute (FWRI); Mote Marine Laboratory; the SeaWiFS Bio-optical Archive and Storage System, ${ }^{24,25}$ and FDEP's Impaired Water Rule database (Run 40). Minimum metadata requirements for field monitoring samples were date, time, latitude, longitude, and Chl- $a$. Latitude and longitude data rounded to the nearest degree or one-half degree were not used. While multiple samples at different depths of chlorophyll existed, the shallowest sample was retained for further analysis. Samples from $>2 \mathrm{~m}$ were excluded. Most of the retained Chl- $a$ data were from discrete samples corrected for phaeopigments. The NEGOM data set used some in-situ fluorometric values, but the fluorometry data were adjusted on the basis of a regression with discrete Chl- $a$ samples. Therefore, all in situ Chl- $a$ data were based on discrete samples corrected for phaeopigments.

\subsection{Satellite Validation}

SeaWiFS-, MODIS-, and MERIS-derived chlorophyll $\left(\mathrm{Chl}_{\mathrm{RS}}-a\right)^{10}$ were validated against field chlorophyll (Chl- $a$ ) measurements using the native resolution of the sensor. The NASA chlorophyll algorithm was applied to MERIS data. The default ocean color algorithms were selected because they were universal algorithms that could be applied to locations beyond Florida and were packaged within the SeaDAS 12gen program. The field observation sampling times were compared to the SeaWiFS, MODIS, and MERIS overpass times. Match-ups were made when samples fell within $\mathrm{a} \pm 3-\mathrm{h}$ time window. ${ }^{26}$

Satellite match-ups were evaluated following the method proposed by Bailey and Werdell. ${ }^{26}$ The field measurement was compared to the geometric mean of the $\mathrm{Chl}_{\mathrm{RS}}-a$ from a $3 \times 3$ block of pixels centered on the sample site. The coefficient of variation of the nine pixels was also determined, if it was greater than $10 \%$ the sample was excluded because of indicated spatial inhomogeneity.

\subsection{Karenia Brevis Bloom Events}

Weekly K. brevis cell counts, for the entire state of Florida, were acquired from FWRI. The FWRI data were binned into 8-day periods that matched the satellite 8-day binning periods. 
Satellite ocean color sensors have a higher probability of correctly identifying $K$. brevis blooms when cell counts were above 50,000 cells L ${ }^{-1} \cdot{ }^{27,28}$ Coastal segments with a single FWRI count greater than 50,000 cells $\mathrm{L}^{-1}$ during an 8-day composite were flagged. The FWRI $K$. brevis cell count data were then spatially matched to the coastal segments in ArcGIS software. $\mathrm{Chl}_{\mathrm{RS}}-a$ data were flagged in any coastal segment for the 8-day period that had a count greater than 50,000 cells $\mathrm{L}^{-1}$. In addition, the same segment was flagged 1 week prior to and after a bloom was detected, unless data indicated lower counts, to provide a temporal buffer as blooms were transported along the coast. Temporal buffers were used to ensure that blooms had dissipated and were no longer in the region of interest.

\subsection{Representative Waters that Support Designated Uses}

CWA section 303(d) impairment listings were reviewed for nutrient, Chl- $a$, and dissolved oxygen listings both in coastal waters and adjacent estuarine segments to ensure that data used in this analysis were representative of waters that support designated uses. Additionally, the historical record of $\mathrm{Chl}_{\mathrm{RS}}-a$ was examined for trends from 1998 to 2009. Removing data from periods of time, when designated use impairments were documented, or highly possible, allowed us to use a data set that only represented water quality conditions supportive of designated uses. The retained data could be used in criteria derivation on the basis of a reference condition approach.

\subsection{Criteria Calculation}

SeaWiFS Chl $\mathrm{RS}^{-} a$ values within coastal segments were extracted by matching segment polygon vertex coordinates with corresponding satellite image pixel and line values on 8-day composites within SeaDAS. The satellite image pixel and line locations were used to build polygons, which were overlaid on the 8-day array with Interactive Data Language (IDL, ITT VIS). Valid values within the polygons were then averaged. ${ }^{9}$

Annual geometric means of $\mathrm{Chl}_{\mathrm{RS}}-a$ in each segment were calculated using only the SeaWiFS satellite data record, based on observations from the reference period (1998 to 2009). Annual geometric means were calculated both including and excluding $K$. brevis bloom events. Criteria values were calculated from the 90th percentile, by segment, of all annual geometric means during the reference period.

\subsection{Transfer from SeaWiFS to MODIS and MERIS}

SeaWiFS data were used to modify MODIS and MERIS data for future assessments in two steps. In the first step, MODIS and MERIS $\mathrm{Chl}_{\mathrm{RS}^{-}} a$ 8-day composite coastal segment data were regressed against corresponding SeaWiFS 8-day composite coastal segment data. Regression coefficients were applied to MODIS and MERIS data, scaling the sensors' responses to SeaWiFS data (from this point forward referred to as scaled MODIS and scaled MERIS). In the second step, the 90th percentile of $\mathrm{Chl}_{\mathrm{RS}}-a$ was calculated for each individual sensor, in each coastal segment, only during the period of sensor overlap. Data from 2003 to 2009 were used because it was the record of overlap for all three missions. The difference (delta) between the SeaWiFS 90th percentile (2003 to 2009) and scaled MODIS or scaled MERIS 90th percentile (2003 to 2009) was calculated (Table 1). This delta value was subtracted as a standardization factor to each annual geometric mean in each coastal segment calculated by MODIS or MERIS. The 90th percentile of $\mathrm{Chl}_{\mathrm{RS}^{-}} a$ calculated with data during the period of sensor overlap, for the second step, should not be confused with the 90th percentile of $\mathrm{Chl}_{\mathrm{RS}^{-}} a$ calculated from only SeaWiFS during the reference period for criteria derivation.

The results of the two step process were verified against SeaWiFS only derived criteria for the reference period. The equivalence of criteria was calculated using a combination of SeaWiFS data from 1998 to 2003 and either (1) replacing the 2003 to 2009 period with MODIS data or (2) replacing the same period with MERIS data. 
Table 1 Difference (delta) at the 90th percentile calculated only during the period of sensor overlap (2003 to 2009) between SeaWiFS and scaled MODIS or scaled MERIS. This delta value was added as a standardization factor to each annual geometric mean in each coastal segment calculated by MODIS or MERIS.

\begin{tabular}{|c|c|c|}
\hline \multicolumn{3}{|c|}{ Standardization factors } \\
\hline Segment & MODIS & MERIS \\
\hline 1 & 0.54 & -0.71 \\
\hline 2 & 0.99 & -0.07 \\
\hline 3 & 0.41 & -0.22 \\
\hline 4 & 0.26 & -0.30 \\
\hline 5 & 0.15 & -0.28 \\
\hline 6 & 0.29 & -0.01 \\
\hline 7 & 0.33 & -0.02 \\
\hline 8 & 0.38 & -0.05 \\
\hline 9 & 0.20 & -0.07 \\
\hline 10 & 0.41 & -0.07 \\
\hline 11 & 0.31 & -0.05 \\
\hline 12 & 0.41 & -0.05 \\
\hline 13 & 0.50 & -0.13 \\
\hline 14 & 0.69 & 0.01 \\
\hline 15 & 0.68 & 0.58 \\
\hline 16 & -0.14 & 0.27 \\
\hline 17 & 0.08 & 1.41 \\
\hline 18 & 0.50 & 0.03 \\
\hline 19 & 0.50 & 0.31 \\
\hline 20 & -0.02 & -0.69 \\
\hline 21 & -0.63 & -1.09 \\
\hline 22 & -0.46 & -0.17 \\
\hline 23 & -1.21 & -0.67 \\
\hline 24 & -2.37 & 0.01 \\
\hline 25 & -2.84 & 0.05 \\
\hline 26 & -4.16 & -0.36 \\
\hline 27 & -1.77 & -0.81 \\
\hline 28 & -2.13 & -0.61 \\
\hline 29 & -0.83 & -0.74 \\
\hline 30 & -0.74 & -0.04 \\
\hline 31 & -0.29 & -0.90 \\
\hline 32 & 0.17 & -0.47 \\
\hline
\end{tabular}


Schaeffer, Hagy, and Stumpf: Approach to developing numeric water quality criteria for coastal waters...

Table 1 (Continued).

\begin{tabular}{|c|c|c|}
\hline \multicolumn{3}{|c|}{ Standardization factors } \\
\hline Segment & MODIS & MERIS \\
\hline 33 & 0.10 & 0.80 \\
\hline 34 & -0.77 & -0.32 \\
\hline 35 & 0.42 & -0.83 \\
\hline 36 & 0.17 & -0.38 \\
\hline 37 & 0.39 & 0.59 \\
\hline 38 & -0.04 & -0.03 \\
\hline 39 & -0.02 & 0.00 \\
\hline 40 & -0.03 & -0.01 \\
\hline 41 & -0.06 & -0.01 \\
\hline 42 & -0.03 & 0.03 \\
\hline 43 & -0.02 & 0.04 \\
\hline 44 & -0.02 & 0.01 \\
\hline 45 & -0.04 & 0.02 \\
\hline 46 & -0.05 & -0.01 \\
\hline 47 & -0.10 & 0.03 \\
\hline 48 & 0.03 & 0.09 \\
\hline 49 & 0.39 & 0.36 \\
\hline 50 & 0.21 & 0.32 \\
\hline 51 & 0.23 & 0.31 \\
\hline 52 & 0.05 & 0.58 \\
\hline 53 & 0.00 & 0.47 \\
\hline 54 & -0.13 & 0.31 \\
\hline 55 & 0.18 & 0.71 \\
\hline 56 & 0.11 & 0.39 \\
\hline 57 & 0.44 & 0.84 \\
\hline 58 & 0.09 & 0.40 \\
\hline 59 & 0.06 & 0.33 \\
\hline 60 & 0.07 & 0.29 \\
\hline 61 & -0.20 & -0.06 \\
\hline 62 & 0.18 & -0.11 \\
\hline 63 & -0.69 & -0.20 \\
\hline 64 & -0.79 & -0.20 \\
\hline 65 & -0.72 & -0.13 \\
\hline
\end{tabular}


Schaeffer, Hagy, and Stumpf: Approach to developing numeric water quality criteria for coastal waters...

Table 1 (Continued).

\begin{tabular}{lcc}
\hline \hline & Standardization factors & \\
\hline Segment & MODIS & MERIS \\
\hline 66 & -0.85 & -0.40 \\
67 & -0.33 & -0.53 \\
68 & -0.47 & -0.08 \\
69 & -0.60 & -0.22 \\
70 & -1.39 & -0.32 \\
71 & -2.00 & -0.38 \\
72 & -1.38 & -0.40 \\
73 & -0.28 & -0.49 \\
74 & -0.16 & -1.17 \\
\hline \hline
\end{tabular}
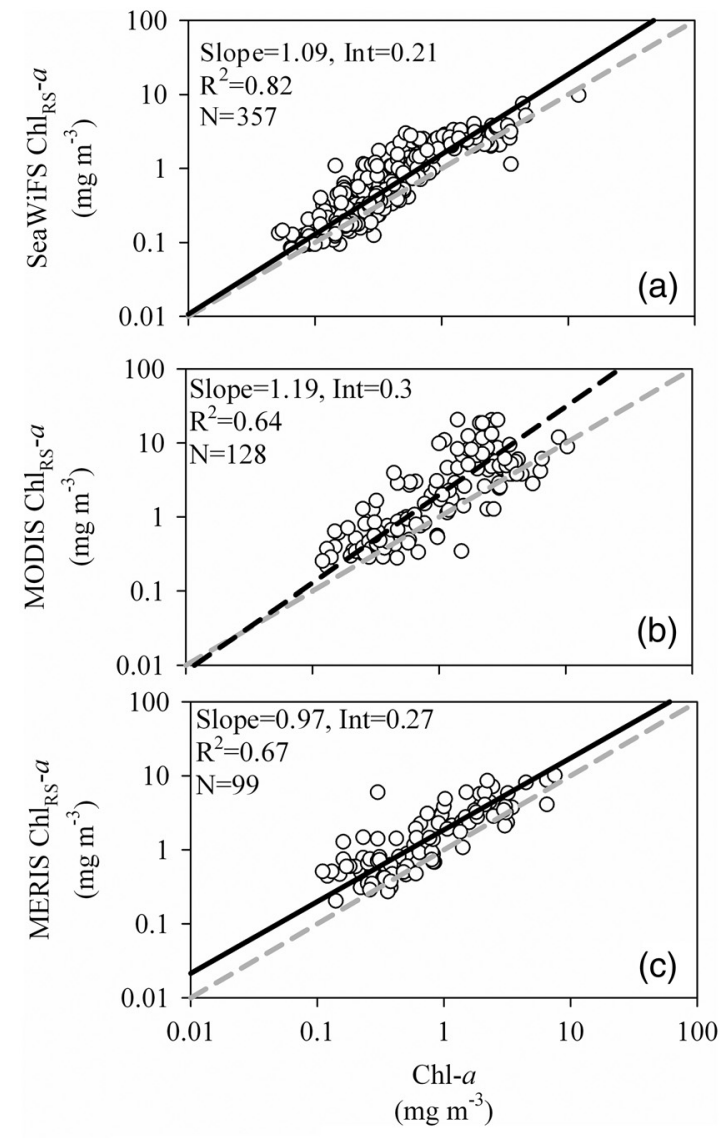

Fig. 2 (a) SeaWiFS, (b) MODIS, (c) and MERIS observations of Chl $\mathrm{RS}^{-}$-a compared to field Chl-a from stations within coastal segments. Gray dashed line is 1:1 fit and black line is regression slope. Plots are presented in log space, but regression coefficients have been converted to linear space to represent a linear regression formula of $y=$ slope $x x+$ intercept. 


\section{Results}

\subsection{Satellite Validation}

A series of regressions were used to ensure that $\mathrm{Chl}_{\mathrm{RS}^{-}} a$ from each of the satellites responded similarly to Chl- $a$. Field Chl- $a$ data included more than 5500 observations between 1998 and 2009 (Fig. 1). The results indicate that SeaWiFS Chl $\mathrm{RS}^{-} a$ correctly represents Chl- $a$ [Fig. 2(a), $\log$ SeaWiFS Chl $\mathrm{RS}-a$ versus log Chl- $a$, slope $\left.=1.09, R^{2}=0.82, p<0.01, N=357\right]$. MODIS and MERIS $\mathrm{Chl}_{\mathrm{RS}}-a$ also represent Chl- $a$ [Fig. 2(b), slope $=1.19, R^{2}=0.64, p<0.01$, $N=128$ ] and $\log$ MERIS $\mathrm{Chl}_{\mathrm{RS}^{-}} a$ were also significant [Fig. 2(c), log $\mathrm{MODIS} \mathrm{Chl}_{\mathrm{RS}^{-}-a \text { versus }}$ $\log$ Chl- $a$, slope $\left.=0.97, R^{2}=0.67, p<0.01, N=99\right]$. The results showed that the chlorophyll- $a$ concentration estimated from satellites is equivalent to the field observations in this region. Therefore, the default $\mathrm{Chl}_{\mathrm{RS}^{-}} a$ algorithm could be used in the coastal segments of this region. No regional tuning or further corrections were applied to the $\mathrm{Chl}_{\mathrm{RS}^{-}} a$ algorithms.

\subsection{Representative Waters that Support Designated Uses}

Several steps were taken to ensure that the data used in the reference condition approach were representative of waters supporting designated uses. Waters that do not meet water quality standards were listed by U.S. states as "water quality limited" under section 303 (d) of the CWA. The review of CWA section 303(d) listings resulted in four coastal segments near Indian River (\#52, 54, 56, and 61; Fig. 1) being screened out during the listing period for dissolved oxygen, nutrients, and Chl- $a$ within a costal segment. Data from segments 52, 54, and 56 were excluded from further analysis between 2003 and 2009. Data from segment 61 were excluded only during 2009. For coastal segments adjacent to FDEP impaired estuaries, 11 additional coastal segments were screened out during the period of designated use impairment. These included segments 51, 53, 55, 57, 58, 62, and 63, which were excluded from further analysis between 2003 and 2009, and segments 47, 50, 59, and 60, which were excluded only during 2009. Screening for CWA section 303(d) listings did not result in the complete removal of the period of record for any coastal segment.

The satellite data were also examined for the presence of long-term $\mathrm{Chl}_{\mathrm{RS}}-a$ trends. The SeaWiFS $\mathrm{Chl}_{\mathrm{RS}^{-}} a$ annual geometric means for all three coastal regions (FP, WFS, and AC) showed no trend from 1998 to 2009 (Fig. 3). Individual linear regressions for each coastal region had nonsignificant trends (FP, $p=0.42$; WFS, $p=0.34$; AC, $p=0.76$ ). Therefore, the reference condition could be based on recent water quality measures between 1998 and 2009.

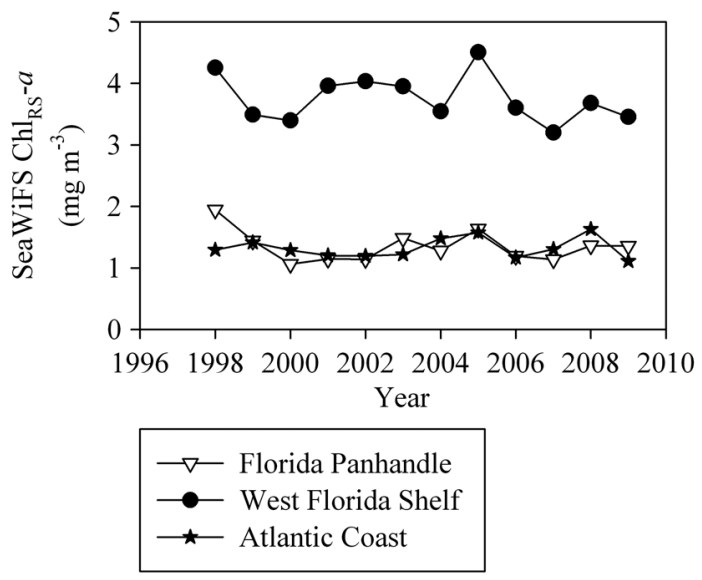

Fig. 3 Annual geometric mean for the three coastal regions in the FP, WFS, and AC from 1998 to 2009. Regression analysis indicated there was no trend in the data between 1998 and 2009 with slopes for each region (FP, $p=0.42$; WFS, $p=0.34$; and $A C, p=0.76$ ) not significantly different from zero. 


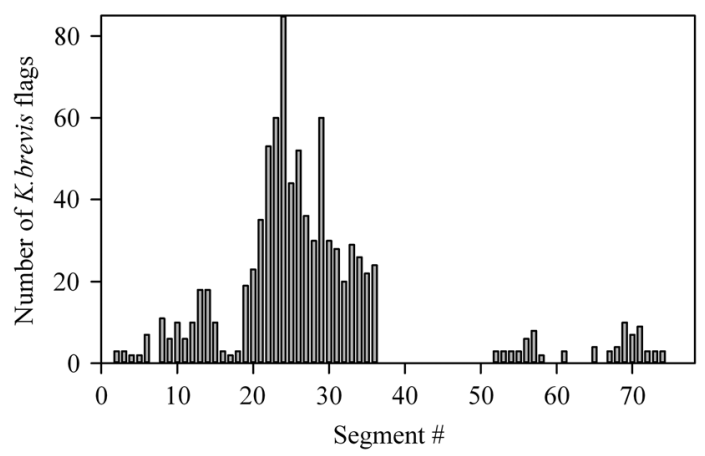

Fig. 4 Number of $K$. brevis events greater than 50,000 cells $L^{-1}$ flagged in each segment.

\subsection{Karenia Brevis Bloom Events}

Around Florida, 23 coastal segments had no reported $K$. brevis blooms $>50,000$ cells L ${ }^{-1}$ between 1998 and 2009 (Fig. 4), and most of the 23 segments without blooms were on the AC. Blooms were more common on the Gulf coast, where only coastal segments 1 and 7 in the FP and 37 on the WFS contained no $K$. brevis blooms $>50,000$ cells L ${ }^{-1}$. Blooms were most common on the WFS, particularly in segments 22 to 26 and 29. In segment 24, 85 bloom events occurred between 1998 and 2009, the highest number in any segment.

\subsection{Criteria Calculation}

As described above, the reference period 90th percentile of the 12 annual geometric means for each coastal segment was calculated for coastal numeric criteria [Fig. 5(a)]. Criteria values ranged from 0.20 to $5.99 \mathrm{mg} \mathrm{m}^{-3}$. Most values were within less than an order of magnitude between 1 and $6 \mathrm{mg} \mathrm{m}^{-3}$ lowest criteria values $\left(0.20\right.$ to $\left.0.3 \mathrm{mg} \mathrm{m}^{-3}\right)$ occurred along the southeast coast of Florida, where waters were strongly affected by the oligotrophic Gulf Stream. ${ }^{29}$
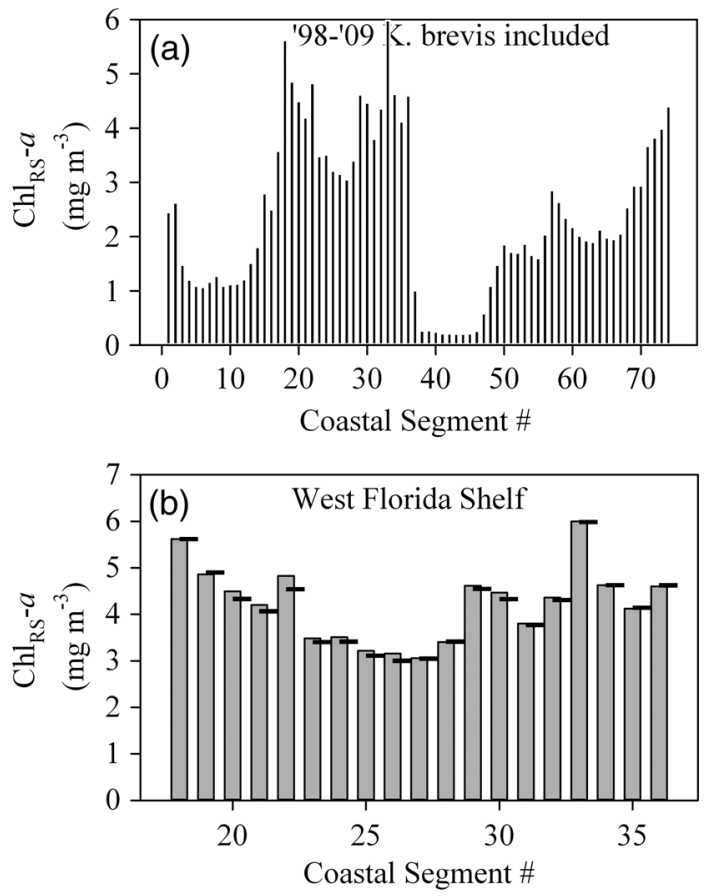

Fig. 5 (a) Reference period 90th percentile estimates of the annual geometric means for all 74 coastal segments could be used as criteria values. (b) WFS reference period 90th percentile estimates with $K$. brevis events included (gray bar) and excluded (flagged, black dash line). 
Criteria were relatively invariant within regions of the coast, particularly in the FP and southeast AC. Criteria for $\mathrm{Chl}_{\mathrm{RS}^{-}} a$ in the WFS region were more heterogeneous than in the other regions.

Among the 51 coastal segments with periods flagged for $K$. brevis, excluding bloom periods resulted in lower criteria values for 24 segments, higher criteria values for 11 segments, and no change for 16 segments [Fig. 5(b)]. The average decrease in 24 segments with criteria values that decreased was $1.93 \%$ with a maximum of $6.00 \%$. The average increase in the 11 coastal segments with an increase was $1.07 \%$ with a maximum increase of $3.9 \%$. The average change overall was a decrease of $0.02 \mathrm{mg} \mathrm{m}^{-3}$ if $K$. brevis was excluded in the criteria value.

\subsection{Transition from SeaWiFS to MODIS and MERIS}

MODIS was linearly related with SeaWiFS [Fig. 6(a), slope $=1.13, R^{2}=0.84, N=507$ ]. MERIS was related to SeaWiFS via a cubic polynomial response [Fig. $6(\mathrm{~b}), R^{2}=0.93$, $N=518]$. Time series of annual geometric means in segment \#1 for SeaWiFS, scaled MODIS, and scaled MERIS illustrate a generally parallel response pattern [Fig. 7(a)]. The intercept adjustment for this segment creates responses that overlap more closely in the standardized response [Table 1, Fig. 7(b)].

Validation tests comparing criteria values based on SeaWiFS and those computed using mixed SeaWiFS/MODIS or SeaWiFS/MERIS time series showed that differences were less than 7\% (Fig. 8). This suggested that the method of scaling and standardizing MODIS and MERIS to SeaWiFS could be used for future water quality assessment relative to the criteria. Only coastal segment \#26 had a large difference (30\%), which resulted from minimal data retrieval by MODIS within that segment.

\section{Discussion}

\subsection{Satellite Validation}

Turbidity might be a concern for interpretation of data from ocean color satellites within estuaries and in coastal waters near sediment-laden rivers. However, rivers in Florida were typically sediment poor. ${ }^{9,30} \mathrm{CDOM}$ and bottom reflectance were also identified as possible interferences

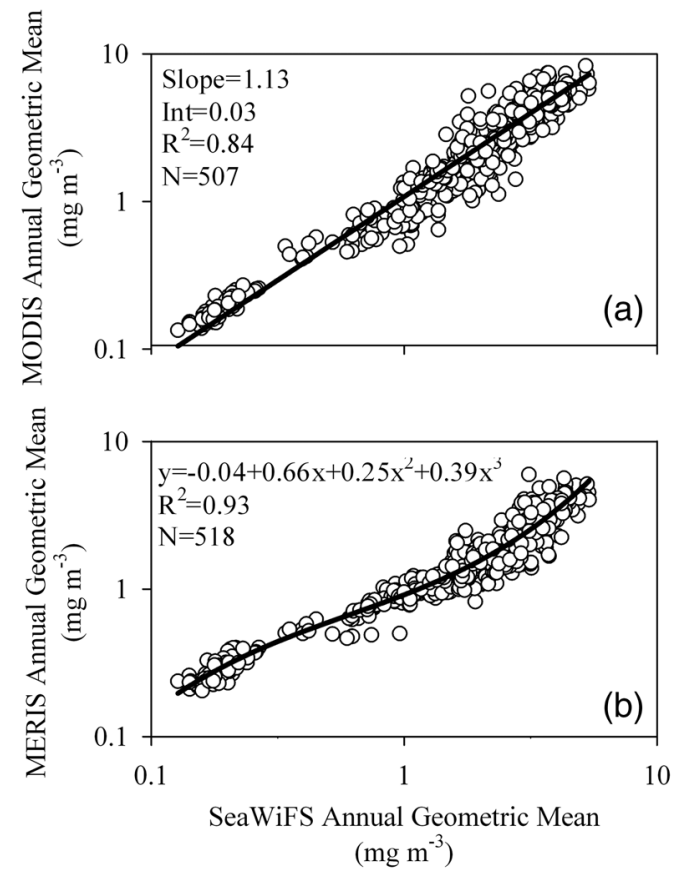

Fig. 6 The $\mathrm{Chl}_{\mathrm{RS}}-\mathrm{a}$ annual geometric mean of each coastal segment from (a) MODIS and (b) MERIS were regressed against SeaWiFS to scale each satellite sensor to a similar response. 


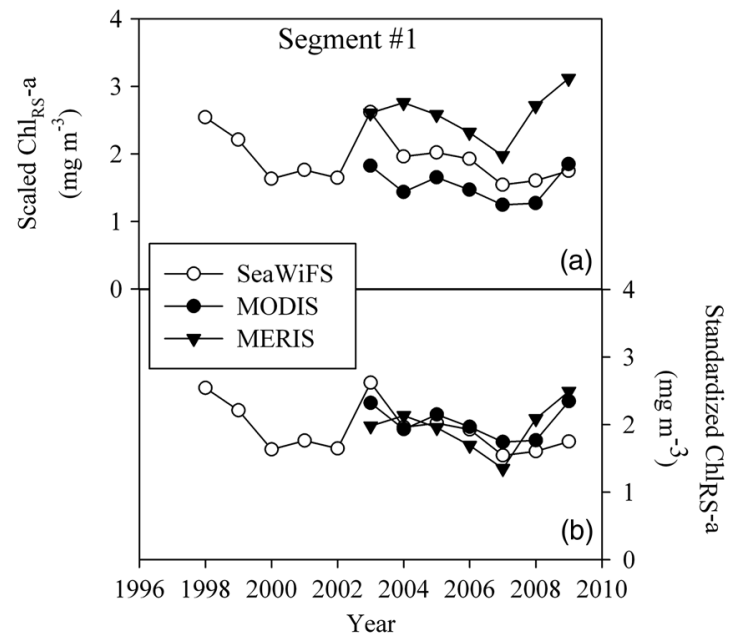

Fig. 7 Example of (a) annual geometric means from SeaWiFS and scaled MODIS and scaled MERIS data for the coastal segment adjacent to Perdido Bay based on the regression coefficients from Fig. 6. Example of (b) annual geometric means from SeaWiFS, scaled MODIS, and scaled MERIS data after applying the standardization (delta) factor.

affecting the relationship between Chl- $a$ and $\mathrm{Chl}_{\mathrm{RS}^{-}}-a$ in coastal waters. To address this, the proposed approach used nonparametric statistics and focused on upper percentiles, so that these interferences, which primarily affect lower percentiles, were unlikely to affect derivation of numeric criteria. ${ }^{9}$ Bottom reflectance was reduced by incorporating the stray light contamination flag, which identified near-shore bins in which reflected light from land enters the satellite's field of view. Bottom reflectance typically influenced the derivation of $\mathrm{Chl}_{\mathrm{RS}}-a$ in waters shallower than 25 m depth. ${ }^{9}$ Shallow depth impacts the resolution of low chlorophyll- $a$ most. Conversely, high chlorophyll- $a$ concentrations reduce the optical depth, thereby reducing bottom effects. As a result, the nonparametric analysis at the high end of the chlorophyll distribution (90th percentile) reduces the impact of bottom reflectance.
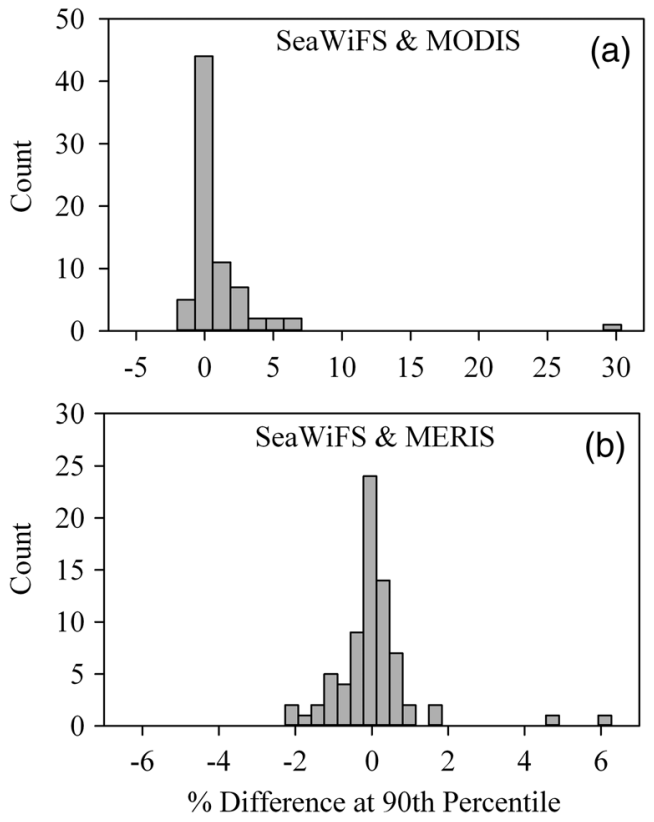

Fig. 8 Percent difference at the 90th percentile compared to only using SeaWiFS for criteria values. (a) Difference when the SeaWiFS record was used from 1998 to 2002 and the data from 2003 to 2009 were replaced with the MODIS record. (b) Difference when the SeaWiFS record was used from 1998 to 2002 and the data from 2003 to 2009 were replaced with the MERIS record. 
Several sources of uncertainty in satellite validation relate to spatial and temporal matching and could explain some of the scatter around the regression lines. Satellite ocean color $\mathrm{Chl}_{\mathrm{RS}}-a$ represents a measure of the geometric mean of Chl- $a$ within the first optical depth of the water column. Only monitoring data from surface samples $(<2 \mathrm{~m})$ were regressed against $\mathrm{Chl}_{\mathrm{RS}^{-}} a$, because there was no consistent reporting of sample depth among the different data sets. Time and space differences between field Chl- $a$ and satellite $\mathrm{Chl}_{\mathrm{RS}}-a$ measures also create error. Ocean color satellite atmospheric corrections were also possible sources of error. ${ }^{31}$

\subsection{Karenia Brevis Bloom Events}

$K$. brevis cell abundance observations from FWRI could be used to exclude the chlorophyll- $a$ signature in the $\mathrm{Chl}_{\mathrm{RS}}-a$ distributions that resulted from $K$. brevis blooms. Although Vargo ${ }^{15}$ concluded that "there is no single hypothesis that can account for blooms," removing data collected during bloom events could ensure that the data points used to derive the statistical distribution of reference conditions represented conditions that supported designated uses.

Retaining $K$. brevis in the analysis was an alternative approach that might have merit because blooms were potentially a natural event in coastal waters. It was important to clarify that $K$. brevis was typically found in background concentrations of 1000 cells $\mathrm{L}^{-1}$, or less, year round. ${ }^{32}$ Historical documentation suggested that $K$. brevis was also a part of the natural floral community of the Gulf of Mexico. Historical records reported observations of K. brevis blooms in the Gulf of Mexico before the $1950 \mathrm{~s}^{33,34}$ and it was still unclear if $K$. brevis blooms have increased in frequency or biomass. ${ }^{35}$ In addition, it was possible that not all K. brevis blooms were detected and flagged. While the FWRI sampling procedure was likely adequate, covering the vast spatial area remained a challenge. ${ }^{27}$ No harmful algal bloom reporting method covered all coastal waters out to $3 \mathrm{NM}$. An alternative approach, therefore, could be to regard $K$. brevis blooms as a natural part of the reference condition and not to exclude flagged observations.

\subsection{Criteria Calculation}

The approach for developing numeric water quality criteria evaluated in this study could potentially be used to compute chlorophyll- $a$ criteria for any coastal waters of similar scale. Coastal segments could be considered water quality limited if a $\mathrm{Chl}_{\mathrm{RS}}-a$ assessment identified an exceedance of the magnitude, frequency and duration of these criteria, triggering the need for action under the U.S. CWA to remediate the waters. For example, the assessment $\mathrm{Chl}_{\mathrm{RS}}-a$ would not exceed the applicable criterion (magnitude) as an annual average (duration) more than once in a 3-year period (frequency). Criteria assessment durations could be a year, while $\mathrm{Chl}_{\mathrm{RS}}-a$ concentrations were calculated as annual geometric means. Frequency and duration components of the criteria allow for natural periods of elevated chlorophyll- $a$ without triggering a determination of impairment.

\subsection{Transition from SeaWiFS to MODIS and MERIS}

Schaeffer et al. ${ }^{9}$ recommended that compliance with $\mathrm{Chl}_{\mathrm{RS}^{-}}-a$ reference condition criteria values be assessed using similar satellite data and algorithms. This will mitigate problems associated with using the ocean chlorophyll 4-band algorithm close to the coast because interferences would be expected to be constant over time. Future assessments with ocean color satellites, such as MODIS and MERIS, could include the calculation of an annual geometric mean for each coastal segment using the SeaDAS $12 \mathrm{gen}$ default $\mathrm{Chl}_{\mathrm{RS}}-a$ algorithm. Either MODIS, MERIS, or a combination of both sensors could be used for an assessment. NASA reprocessing events do occur occasionally, which could improve the response of $\mathrm{Chl}_{\mathrm{RS}}-a$ from the satellite. To address the issue of NASA satellite reprocessing events, an annual geometric mean could be calculated from a specified period. The 90th percentile would be determined for this period for the previous process and the new process, and the difference used to correct the assessment as a part of the standardization. 
This approach could also be transferred to other satellites such as the VIIRS, PACE satellite, and the OLCI on Sentinel-3. Multimission ocean color satellites are necessary to provide the future climate data record ${ }^{36}$ necessary to continue the assessment process. This study addressed merging missions and, briefly, reprocessing events. ${ }^{37}$ Further discussion is required on how to incorporate newer algorithms, ${ }^{38,39}$ advanced atmospheric corrections, and the stability between $\mathrm{Chl}_{\mathrm{RS}^{-}} a$ and Chl- $a$, all of which could be considered during periodic re-evaluations of water quality criteria.

Few efforts have focused on creating a continuous assessment of $\mathrm{Ch}_{\mathrm{RS}^{-}} a$, and a standard method for developing multimission ocean color products has not yet been established to date. ${ }^{40}$ Many issues confound the ability to merge multiple ocean color missions, including data processing algorithms; validation efforts; different spectral bands, band widths and sensitivities; and flyovers during different times of day ${ }^{36,40}$ Previous attempts at merging multimission products typically focused at the global scale ${ }^{36,41,42}$ with only a few reports at the regional scale. ${ }^{31,43}$ Regardless of spatial scale, the SeaWiFS satellite was universally used as the ocean color baseline satellite because it was well characterized, validated and stable. ${ }^{40}$ This report presented the first method for long-term ocean color record merging in coastal waters, in this case applied to water quality assessments.

\subsection{Use of Satellites for Assessment Frameworks}

Satellite ocean color products provided the advantage of monitoring at spatial and temporal scales that cannot be matched by traditional field monitoring. Assessment frameworks often include infrequent field sampling of the coastal ocean due to logistical and financial constraints. Thus, use of satellite imagery to assess eutrophication impacts in coastal waters can provide a low cost and high return solution. Satellite ocean color has been previously recommended for a water quality assessment framework. Australia has considered a satellite approach under the National Water Quality Management Strategy, which provided guidelines for numerical concentration limits on a variety of water quality parameters. ${ }^{44}$ The MSFD included marine waters up to $200 \mathrm{NM}$ from the European exclusive economic zone, for which ocean color measures may be the only realistic approach. ${ }^{6}$ Numerous methods have also been developed to support the goals of the WFD (Refs. 45-47) and OSPAR (Ref. 48) throughout Europe.

\section{Conclusions}

SeaWiFS $\mathrm{Chl}_{\mathrm{RS}^{-}} a$ quantified a baseline associated with designated use attainment and assessment data that could reveal changes that may cause loss of support for aquatic life uses. The SeaWiFS satellite was used as the ocean color baseline satellite because it was well characterized, validated and stable. This report presented the first method for long-term ocean color record merging in coastal waters applied to water quality assessments. Ocean color mission overlap between sensors was necessary for developing an approach to continue assessments via satellite remote sensing, as new missions become operational and other missions are concluded.

\section{Acknowledgments}

The information in this document has been funded in part by the U.S. Environmental Protection Agency. It has been subjected to review by the National Health and Environmental Effects Research Laboratory and approved for publication. Approval does not signify that the contents reflect the views of the agency, nor does mention of trade names or commercial products constitute endorsement or recommendation for use. Tetra Tech, Inc. queried in situ data for satellite match-ups. We thank Zhong Ping Lee at University of Massachusetts, Boston, Curtiss Davis at Oregon State University, Steven Lohrenz at University of Massachusetts, Dartmouth, Chuanmin $\mathrm{Hu}$ at University of South Florida, and Richard Gould at the Naval Research Laboratory for their comments and recommendations in developing this approach. 


\section{References}

1. B. L. Peierls et al., "Human influence on river nitrogen," Nature 350, 386-387 (1991), http://dx.doi.org/10.1038/350386b0.

2. N. N. Rabalais et al., "Hypoxia in the northern Gulf of Mexico: does the science support the plan to reduce, mitigate, and control hypoxia," Estuar. Coast. 30(5), 753-772 (2007).

3. R. W. Howarth et al., "Regional nitrogen budgets and riverine N\&P fluxes for the drainages to the north Atlantic Ocean: natural and human influences," Biogeochemistry 35(1), 75-139 (1996), http://dx.doi.org/10.1007/BF02179825.

4. R. W. Howarth et al., "Nutrient pollution of coastal rivers, bays and seas," Issues Ecol. 7, $1-14(2000)$.

5. U.S. EPA, "National strategy for the development of regional nutrient criteria," p. 47, U.S. Environmental Protection Agency, Washington, DC (1998).

6. J. G. Ferreira et al., "Overview of eutrophication indicators to assess environmental status within the European Marine Strategy Framework Directive" Estuar. Coast. Shelf Sci. 93, 117-131 (2011), http://dx.doi.org/10.1016/j.ecss.2011.03.014.

7. M. Devlin, S. Bricker, and S. Painting, "Comparison of five methods for assessing impacts of nutrient enrichment using estuarine case studies," Biogeochemistry 106, 177-205 (2011), http://dx.doi.org/10.1007/s10533-011-9588-9.

8. J. Foden et al., "Searching for undesirable disturbance: an application of the OSPAR eutrophication assessment method to marine waters of England and Wales," Biogeochemistry 106(2), 157-175 (2010), http://dx.doi.org/10.1007/s10533-010-9475-9.

9. B. A. Schaeffer et al., "An approach to developing numeric water quality criteria for coastal waters using the SeaWiFS satellite data record," Environ. Sci. Technol. 46, 916-922 (2012), http://dx.doi.org/10.1021/es2014105.

10. J. E. O'Reilly et al., "Ocean color chlorophyll algorithms for SeaWiFS," J. Geophys. Res. 103(C11), 24,937-924,953 (1998), http://dx.doi.org/10.1029/98JC02160.

11. R. S. Lunetta et al., "Measurement of water colour using AVIRIS imagery to assess the potential for an operational monitoring capability in the Pamlico Sound Estuary, USA," Int. J. Rem. Sens. 30(13), 3291-3314 (2009), http://dx.doi.org/10.1080/ 01431160802552801.

12. P. J. Werdell et al., "Regional and seasonal variability of chlorophyll- $a$ in Chesapeake bay as observed by SeaWiFS and MODIS-Aqua," Rem. Sens. Environ. 113, 1319-1330 (2009), http://dx.doi.org/10.1016/j.rse.2009.02.012.

13. K. A. Steidinger et al., "Bloom dynamics and physiology of Gymnodinium breve with emphasis on the Gulf of Mexico," in Physiological Ecology of Harmful Algal Blooms, D. M. Anderson, A. D. Cembella, and G. M. Hallegraeff, Eds., pp. 133-153, SpringerVerlag, Berlin (1998).

14. J. H. Landsberg, "The effects of harmful algal blooms on aquatic organisms," Rev. Fish. Sci. 10(2), 113-390 (2002), http://dx.doi.org/10.1080/20026491051695.

15. G. A. Vargo, "A brief summary of the physiology and ecology of Karenia brevis Davis (G. Hansen and Moestrup comb. nov.) red tides on the West Florida Shelf and of hypotheses posed for their initiation, growth, maintenance and termination," Harmful Algae 8, 573-584 (2009), http://dx.doi.org/10.1016/j.hal.2008.11.002.

16. M. Tomlinson et al., "Evaluation of the use of SeaWiFS imagery for detecting Karenia brevis harmful algal blooms in the eastern Gulf of Mexico," Rem. Sens. Environ. 91, 293-303 (2004), http://dx.doi.org/10.1016/j.rse.2004.02.014.

17. P. R. Carlson and K. Madley, "Statewide summary for Florida," in Seagrass Status and Trends in the Northern Gulf of Mexico: 1940-2002, L. Handley, D. Altsman, and R. DeMay, Eds., pp. 100-113, U.S. Environmental Protection Agency, Washington, DC (2006).

18. S. L. Morey, D. S. Dukhovskoy, and M. A. Bourassa, "Connectivity of the Apalachicola River flow variability and the physical and bio-optical oceanic properties of the northern West Florida Shelf," Cont. Shelf Res. 29, 1264-1275 (2009), http://dx.doi.org/10.1016/j.csr .2009.02.003. 
19. G. C. Feldman and C. R. McClain, "Ocean Color Web, SeaWiFS and MODIS Reprocessing 2009.1," 2009, http://oceancolor.gsfc.nasa.gov/ (29 5 2010).

20. K. Baith et al., "SeaDAS: Data analysis system developed for ocean color satellite sensors," EOS Trans. Am. Geophys. Union 82(18), 202 (2001), http://dx.doi.org/10.1029/ $01 \mathrm{EO} 00109$.

21. R. A. Arnone et al., "Coastal optical properties using SeaWiFS," in Proceedings: Ocean Optics XIV Meeting, Kona, HI (1998).

22. R. P. Stumpf et al., "A partially-coupled ocean-atmosphere model for retrieval of waterleaving radiance from SeaWiFS in coastal waters," in Algorithm Updates for the Fourth SeaWiFS Data Reprocessing, S. B. Hooker, Ed., pp. 51-59, NASA Technical Memo, Greenbelt, Maryland (2003).

23. S. W. Bailey, B. A. Franz, and P. J. Werdell, "Estimation of near-infrared water-leaving reflectance for satellite ocean color data processing," Ocean Opt. 18(7), 7521-7527 (2010), http://dx.doi.org/10.1364/OE.18.007521.

24. P. J. Werdell and S. W. Bailey, The SeaWiFS Bio-optical Archive and Storage System (SeaBASS): Current architecture and implementation, p. 45, NASA Goddard Space Flight Center, Greenbelt, MD (2002).

25. P. J. Werdell et al., "Unique data repository facilitates ocean color satellite validation," $E O S$ Trans. Am. Geophys. Union 84(38), 377 (2003), http://dx.doi.org/10.1029/2003EO380001.

26. S. W. Bailey and P. J. Werdell, "A multi-sensor approach for the orbit validation of ocean color satellite data products," Rem. Sens. Environ. 102, 12-23 (2006), http://dx.doi.org/ 10.1016/j.rse.2006.01.015.

27. C. A. Heil and K. A. Steidinger, "Monitoring, management, and mitigation, of Karenia blooms in the eastern Gulf of Mexico," Harmful Algae 8, 611-617 (2009), http://dx.doi .org/10.1016/j.hal.2008.11.006.

28. P. A. Tester, R. P. Stumpf, and K. Steidinger, "Ocean color imagery: what is the minimum detection level for Gymnodium breve blooms?", in Proc. VIII Int. Conf. Harmful Algae, B. Reguera et al., Eds., pp. 149-151, Xunta de Galicia and IOC of UNESCO, Santiago, Spain (1998).

29. D. B. Olson, O. B. Brown, and S. R. Emmerson, "Gulf stream frontal statistics from Florida Straits to Cape Hatteras derived from satellite and historical data," J. Geophys. Res. 88(C8), 4569-4577 (1983), http://dx.doi.org/10.1029/JC088iC08p04569.

30. J. P. Cannizzaro et al., "A novel technique for detection of the toxic dinoflagellate, Karenia brevis, in the Gulf of Mexico from remotely sensed ocean color data," Cont. Shelf Res. 28, 137-158 (2008), http://dx.doi.org/10.1016/j.csr.2004.04.007.

31. C. Zhang et al., "Bridging between SeaWiFS and MODIS for continuity of chlorophyll-a concentration assessments off Southeastern China," Rem. Sens. Environ. 102, 250-263 (2006), http://dx.doi.org/10.1016/j.rse.2006.02.015.

32. M. Geesey and P. A. Tester, "Gymnodinium breve: ubiquitous in Gulf of Mexico waters?," in Toxic Phytoplankton Blooms in the Sea, T. J. Smayda and Y. Shimizu, Eds., pp. 251-255, Elsevier, Amsterdam (1993).

33. J. J. Walsh et al., "Isotopic evidence for dead fish maintenance of Florida red tides, with implications for coastal fisheries over both source regions of the West Florida shelf and within downstream waters of the South Atlantic Bight," Prog. Oceanogr. 80(1-2), 51-73 (2009), http://dx.doi.org/10.1016/j.pocean.2008.12.005.

34. K. A. Steidinger, "Historical perspective on Karenia brevis red tide research in the Gulf of Mexico," Harmful Algae 8(4), 549-561 (2009), http://dx.doi.org/10.1016/j.hal.2008.11.009.

35. D. M. Anderson et al., "Harmful algal blooms and eutrophication: examining linkages from selected coastal regions of the United States," Harmful Algae 8(1), 39-53 (2008), http:// dx.doi.org/10.1016/j.hal.2008.08.017.

36. W. W. Gregg and N. W. Casey, "Improving the consistency of ocean color data: a step toward climate data records," Geophys. Res. Lett. 37, L04605 (2010)http://dx.doi.org/ 10.1029/2009GL041893.

37. C. McClain, G. C. Feldman, and S. B. Hooker, "An overview of the SeaWiFS project and strategies for producing a climate research quality global ocean bio-optical time series," Deep. Sea Res. Part II 51(1-3), 5-42 (2004), http://dx.doi.org/10.1016/j.dsr2.2003.11.001. 
38. F. Gohin, J. N. Druon, and L. Lampert, "A five channel chlorophyll concentration algorithm applied to SeaWiFS data processed by SeaDAS in coastal waters," Int. J. Rem. Sens. 23(8), 1639-1661 (2002), http://dx.doi.org/10.1080/01431160110071879.

39. C. Dupouy et al., "Inherent optical properties and satellite retrieval of chlorophyll concentration in the lagoon and open ocean waters of New Caledonia," Mar. Pollut. Bull. 61, 503-518 (2010), http://dx.doi.org/10.1016/j.marpolbul.2010.06.039.

40. E. Kwiatkowska, "Ocean color data merger," in MODIS Validation, Data Merger and Other Activities Accomplished by the SIMBIOS Project: 2002-2003, G. S. Fargion and C. R. McClain, Eds., pp. 50-73, Goddard Space Flight Center, Greenbelt, MD (2003).

41. W. W. Gregg and M. E. Conkright, "Decadal changes in global ocean chlorophyll," Geophys. Res. Lett. 29(15), 20-1-20-4 (2002), http://dx.doi.org/10.1029/2002GL014689.

42. D. Antoine et al., "Bridging ocean color observations of the 1980s and 2000s in search of long term trends," J. Geophys. Res. 110, C06009 (2005), http://dx.doi.org/10.1029/ 2004JC002620.

43. C. Hu et al., "Comparison of ocean color data products from MERIS, MODIS, and SeaWiFS: preliminary results for the east China seas," in Proc. Envisat Symp., H. Lacoste and L. Ouwehand, Eds., p. 462503, ESA Communication Production Office, Noordwijk (2007).

44. A. G. Dekker and E. L. Hestir, "Evaluating the feasibility of systematic inland water quality monitoring with satellite remote sensing," CSIRO: Water for a Healthy Country National Research Flagship, Canberra, Australia (2012).

45. M. Bresciani et al., "Assessing remotely sensed chlorophyll-a for the implementation of the Water Framework Directive in European perialpine lakes," Sci. Total Environ. 409, 3083-3091 (2011), http://dx.doi.org/10.1016/j.scitotenv.2011.05.001.

46. Q. Chen, Y. Zhang, and M. Hallikainen, "Water quality monitoring using remote sensing in support of the EU water framework directive (WFD): a case study in the Gulf of Finland," Environ. Monitor. Assess. 124, 157-166 (2007), http://dx.doi.org/10.1007/s10661-006-9215-8.

47. R. B. Domingues, A. Barbosa, and H. Galvão, "Constraints on the use of phytoplankton as a biological quality element within the Water Framework Directive in Portuguese waters," Mar. Pollut. Bull. 56, 1389-1395 (2008), http://dx.doi.org/10.1016/j.marpolbul.2008.05.006.

48. Y.-J. Park, K. Ruddick, and G. Lacroix, "Detection of algal blooms in European waters based on satellite chlorophyll data from MERIS and MODIS," Int. J. Rem. Sens. 31(24), 6567-6583 (2010), http://dx.doi.org/10.1080/01431161003801369.

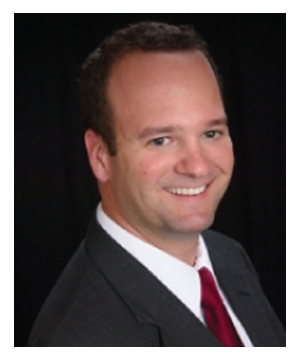

Blake A. Schaeffer earned his $\mathrm{PhD}$ in marine science from North Carolina State University studying harmful algal bloom ecology. He then served in two post-doctorate positions. The first was a NASA funded project with the University of North Carolina at Wilmington to investigate the impacts of El Nino/La Nina cycles on ecosystem biodiversity in Galapagos, Ecuador. The second post-doctorate was with the U.S. Environmental Protection Agency quantifying optical properties related to the Gulf of Mexico hypoxic zone. His current focus is on the use of remote sensing technology to monitor water quality. Research interests broadly cover deriving water quality parameters in coasts, estuaries, and lakes using Landsat, SeaWiFS, MODIS, MERIS, and HICO. His management interests generally include integrating remote sensing technologies into decision support frameworks.

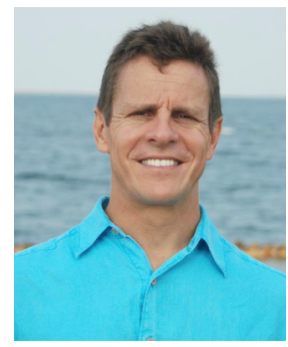

James D. Hagy is an estuarine ecologist whose research addresses eutrophication in estuaries and coastal waters from a variety of perspectives. He completed his graduate studies at the University of Maryland Center for Environmental Science, where he focused on hypoxia in the Chesapeake Bay region. He has since worked in the northern Gulf of Mexico and northwest Florida estuaries. He has always thought of his research in terms of the potential application to solving environmental problems, perhaps an outgrowth of his association as a student with the U.S. EPA Chesapeake Bay Program. He has since worked at the U.S. 
Environmental Protection Agency, first as a post-doc, and later as a research scientist working in northwest Florida. His current research addresses nutrients in coastal waters and nutrient management, supporting EPA Office of Water and several states in their nutrient management programs.

Richard P. Stumpf has responsibilities in improving forecasts of harmful algal blooms and in developing and applying remotely sensed satellite to coastal regions. He has had lead responsibility in transitioning research to operations for the NOAA Harmful Algal Bloom Forecast System in the Gulf of Mexico. In addition, he conducts research to improve assessment of habitat change, eutrophication and monitoring of algal blooms and water quality. His studies have encompassed a range of sensors, including AVHRR, Landsat, SeaWiFS and more recent ocean color sensors, and have significantly expanded the capabilities of these sensors in coastal waters. His research has included most of the U.S. east and Gulf coasts, the upper Great Lakes and central California, with studies on such topics as the transport of red tide in the southeast, water clarity and seagrass loss in Florida Bay, the impact of floods on estuaries, and marsh stability in Florida and Delaware. 